\title{
The Role of Exchange Rates in Intertemporal Risk-Return Relations:
}

\author{
Turan G. Balia $\mathrm{a}^{\circ}$, Liuren $\mathrm{Wu}^{\mathrm{a}}$ 青

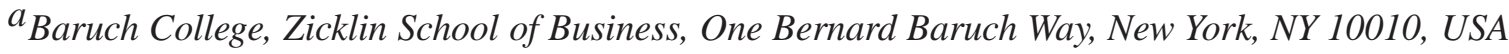

(First draft March 17, 2004; this version May 18, 2010)

\begin{abstract}
This paper investigates the significance of an intertemporal relation between expected returns on countries' stock market portfolios and their risk exposures to the world market portfolio. We find that the intertemporal risk-return relation differs significantly under different currency denominations. The slope coefficient is the largest at around seven when the returns are denominated in Japanese yen, moderate at about five when the returns are denominated in the Canadian or US dollars, and the smallest at around three when the returns are denominated in pound or euro and its predecessors. The ranking of the risk-return coefficients across different currency denominations remains the same when we replace country equity indices with global industry portfolios in estimating the intertemporal relations, when we change the return frequency from monthly to daily, and when we consider different specifications for the conditional covariance process.
\end{abstract}

JEL Classifications: G12, C32, F30, F31.

Keywords: Exchange rate, international capital asset pricing, conditional covariance; risk aversion.

\footnotetext{
${ }^{*}$ We thank James Lothian (the editor), David Backus, Gurdip Bakshi, Nikunj Kapadia, Hosssein Kazemi, James Lothian, Cornelia McCarthy, Sergei Sarkissian, and seminar participants at Fordham University for comments. We also thank Ozgur Demirtas for discussions and for help on model estimation.

${ }_{\dagger}^{\dagger}$ Tel.: +1-646-312-3506; fax: +1-646-312-3451. E-mail address: turan.bali@baruch.cuny.edu

†Corresponding author. Tel.: +1-646-312-3509; fax: +1-646-312-3451. E-mail address: liuren.wu@ @aruch.cuny.edu
} 


\section{Introduction}

The intertemporal relation between risk and return in the stock market has been one of the most extensively studied topics in financial economics. In a seminal paper, Merton (1973) derives an intertemporal capital asset pricing model (ICAPM) for a single economy. According to this model and under constant investment opportunity, the conditional expected excess return on a stock or stock portfolio is proportional to its covariance with the market portfolio return in that economy, with the slope coefficient reflecting the average relative risk aversion of market investors. The literature has examined this intertemporal relation extensively within the single economy framework 1

In a financially integrated international economy, the benefit of international diversification suggests that investors should hold the global market portfolio instead of a country-specific market portfolio. Accordingly, the expected excess return on a stock or stock portfolio should be proportional to its covariance with the global market portfolio return. In this paper, we investigate the significance of the risk-return tradeoff in an international ICAPM framework and estimate the magnitude of the average risk aversion to the world market portfolio. More importantly, we measure how this risk aversion estimate varies with different currency denominations.

A key difference in the global economy is that investing in foreign stocks incurs exposure to exchange rate risk. Even if investors can trade foreign stocks without incurring much extra cost than trading domestic stocks in an integrated global financial market, converting investments in the foreign stocks to domestic consumption faces the exchange rate risk between the two economies. In a world with financial market integration but goods market segmentation, investors can invest globally but their consumption is limited mainly to their local currencies. In this paper, we explicitly recognize the role of exchange rate risk when estimating the intertemporal risk-return relations in international economies. On the one hand, we assume international financial market integration among the industrialized countries, and link the expected excess returns of industrialized country or industry portfolios to their conditional covariance with the global market portfolio, with one common proportionality coefficient. On the other hand, we allow this common coefficient to differ when we estimate the intertemporal risk-return relations under different currency denominations. The difference in the coefficient estimates reflects the degree of goods market segmentation and the pricing of exchange rate risk. More importantly, it also reflects the differences in risk preferences among consumers that are limited to

\footnotetext{
${ }^{1}$ Prominent examples include French, Schwert, and Stambaugh (1987), Campbell (1987), Chou (1988), Scruggs (1998), Baillie and DeGennaro (1990), Nelson (1991), Campbell and Hentschel (1992), Chan, Karolyi, and Stulz (1992), Chou, Engle, and Kane (1992), Glosten, Jagannathan, and Runkle (1993), Whitelaw (1994), Harvey (1989, 2001), Goyal and Santa-Clara (2003), Brandt and Kang (2004), Bollerslev and Zhou (2006), Ghyselsa, Santa-Clarab, and Valkanov (2005), Guo and Whitelaw (2006), and Bali (2008).
} 
consume in their local currencies.

In contrast to our focus on the intertemporal relation variation across different currency denominations, many empirical works on international capital asset pricing ignore the exchange rate risk and its implications for potentially different risk-return relations under different currency denominations. Empirical studies either focus on the risk-return relation under one currency denomination (e.g., the US dollar) or assume that the same risk-return relation holds across all currency denominations 2 The motivation of these studies can go back to Solnik (1974), who does not give an explicit role for the exchange rate by imposing a special correlation structure 3 or to Grauer, Litzenberger, and Stehle (1976), who assume that purchasing power parity holds. In reality, however, although the financial markets are becoming increasingly integrated globally, goods transportation is still costly and labor mobility remains limited. Consumption risk sharing is incomplete. As a result, real exchange rate persistently deviates from the parity condition, with the deviations both large and volatile (Rogoff (1996)). Furthermore, the nominal exchange rate movement often defies the prediction of the uncovered interest rate parity, showing that the exchange rate is not only priced, but risk premium is also time-varying 4

We start our analysis using monthly data from January 1970 to December 2004 on the MSCI global index returns and returns on seven equity indices for the G7 countries. First, we compute monthly returns on the eight indices based on one currency denomination. We calculate the excess returns as the index return minus the short-term interest rate in that currency. Second, we estimate the conditional covariances between the excess returns on the world market portfolio and the excess returns on the seven country indices using a bivariate GARCH specification. Third, we estimate the common relation of the seven simultaneous equations implied by the international version of the intertemporal capital asset pricing model between the expected excess returns on the seven country indices and the corresponding conditional covariances. We repeat the above procedure and estimate the intertemporal risk-return relation under each of the seven currency denominations. Under each currency denomination, one common slope applies to all seven risk-return equations, as suggested by the global financial market integration. However, we allow the coefficient estimates to be different when we estimate the relation under different currency denominations, capturing the potential impact of differences in risk preferences and goods market segmentation.

\footnotetext{
${ }^{2}$ Prominent empirical works on international capital asset pricing include Harvey (1991), Chan, Karolyi, and Stulz (1992), Ferson and Harvey (1993), Bekaert and Harvey (1995), De Santis and Gerard (1997), and Cavaglia, Hodrick, Vadim, and Zhang (2002).

${ }^{3}$ See Sercu (2003) for a critical discussion and generalization of this result.

${ }^{4}$ Many studies document this phenomenon and many more attempt to account for its existence. Prominent examples include Hsieh (1984), Mishkin (1984), Hodrick (1987), Bekaert and Hodrick (1992), Backus, Gregory, and Telmer (1993), Bekaert (1995), Dumas and Solnik (1995), Engel (1996), Flood and Rose (1996), Bakshi and Naka (1997), Bansal (1997), Bansal and Dahlquist (2000), and Backus, Foresi, and Telmer (2001).
} 
Under all seven currency denominations, the risk-return coefficient estimates are positive and statistically significant. Nevertheless, the coefficient estimates are quite different under different currency denominations, showing the significance of goods market segmentation and differences in risk preferences for consumers in different economic regions. The risk-return coefficient estimate is the highest at about seven when returns are denominated in Japanese yen, suggesting that investors who consume mainly in yen-denominated goods ask for the highest return for the same risk level. By comparison, the coefficient estimates are the lowest at around three when the returns are denominated in pound or euro and its predecessors. The coefficient estimates are around five when the returns are denominated in either Canadian or US dollars. The coefficient differences across the three economic regions are statistically significant.

To study whether country-specific risks are priced in addition to the global portfolio, we regress the country index returns on the global index returns and use the residuals to denote country-specific risks. Then, we estimate the conditional covariance between the country index returns and the residual risks in that country. We add this covariance term to the simultaneous equations and test whether the coefficient estimates on this term are statistically significant. The coefficient estimates on this covariance term are insignificant in all cases, suggesting that the G7 countries are integrated financially. Nevertheless, with or without this residual term, the slope coefficient estimates on the covariance with the global index returns are always statistically significant, but different in magnitude under different currency denominations. The ranking of the coefficient estimates does not change whether we add the covariance term with the country-specific risk or not.

In a world with financial integration but goods segmentation, the intertemporal risk-return relation does not depend on how the financial securities are grouped into different portfolios, but depends on the currency denomination under which the returns are computed for these portfolios. To emphasize this point, we reestimate the intertemporal risk-return relation using monthly data on global industry portfolios. Datastream provides return data on 24 global industry portfolios and a global market portfolio on industrialized countries. We postulate that the expected excess returns on these industry portfolios are proportional to their conditional covariance with the global portfolio return, with the coefficient common among all industry portfolios but different across different currency denominations. The estimation results confirm our hypothesis. Under each currency denomination, the common slope estimate from the 24 industry portfolios is similar to the estimate from the seven country-index portfolios. Across different currency denominations, the coefficient estimates maintain the same ranking, with the coefficient on yen the largest, followed by Canadian and US dollars, and then by the European currencies.

For robustness check, we repeat the estimation using daily return data on both country-index portfolios 
and industry portfolios. We also consider different GARCH specifications and different distributional assumptions in the conditional covariance estimation. In each case, the coefficient estimates on the covariance with the world market portfolio remain similar and the rankings remain the same across different currency denominations.

Therefore, as our key contribution to the literature, we explicitly address the pricing of currency risk and show that the risk-return relation differs under different currency denominations. On the surface, the estimation shows that currency risks are priced, a result that is also obtained from studies on, for example, uncovered interest rate parity. In a deeper level, our results reveal the different risk attitudes and pricing among investors that consume in different currency-denominated economies. Taken together, our study highlights the fact that exchange rate dynamics are neither exogenously given, nor tangential to asset pricing, but rather very informative about the pricing differences across different economies.

The rest of the paper is structured as follows. The next section describes the data set and the estimation methodology. Section 3 presents the results based on monthly returns on country-index portfolios. Section 4 discusses the results based on monthly returns on global industry portfolios. Section 5 performs robustness analysis by re-estimating the relations using daily returns and by considering alternative specifications for the conditional covariance estimation. Section 6 concludes.

\section{Data and estimation}

\subsection{Data}

We estimate the intertemporal risk-return relation using both country-index portfolio returns and industry portfolio returns. The monthly data on country index portfolio returns are from MSCI on the G7 countries: the United States, Canada, Japan, the United Kingdom, Italy, Germany, and France. MSCI also provides a monthly global market index portfolio, which we use as the world market portfolio risk factor. The monthly data are from January 1970 to December 2004. We download the country index data both in dollar denominations and in their respective local currencies, and compute the monthly log returns. The difference between the dollar return and the local currency return on each index equals the return on the dollar price of the local currency. We use these currency return series to convert dollar returns on all seven country-index portfolios into returns on each of the other six currency denominations. The daily returns on country indices and the world market portfolio are from Datastream, covering the period from January 2, 1973 to December 31, 2004. 
The industry portfolio data are also from Datastream, which provides 24 global industry portfolios constructed for industrialized countries. Global industry returns are formed by the market capitalization weighted average of local industry returns. Data for the industry portfolios are available in both daily and monthly frequency for the same sample period. To compute excess returns, we use the short-term riskfree rate from each currency, collected from various sources to match our sample period on the country and industry portfolios.

Appendix $\mathrm{A}$ reports the sample estimates of mean, standard deviation, skewness, excess kurtosis, and the Jarque-Bera (JB) statistics for the monthly excess returns (in annualized percentages) on the country and global index portfolios under each of the seven currency denominations. The statistics show substantial variation across different currency denominations, implying a significant impact of exchange rates on the country and global portfolio returns. The return skewness estimates are generally small, but the excess kurtosis statistics are high and significantly different from zero in most cases. The JB statistic is a formal statistic for return non-normality based on the skewness $(S)$ and excess kurtosis $(K)$ estimates, $J B=T\left[\left(S^{2} / 6\right)+K^{2} / 24\right]$, with $T$ denoting the number of observations. The JB statistic has a Chi-square distribution with two degrees of freedom under the null of normal distribution, with the critical values at the $10 \%, 5 \%$, and $1 \%$ significance level being 4.61, 5.99, and 9.21, respectively. The JB statistics indicate strong rejection of the normality assumption for the excess returns on most country-index portfolios. The non-normality in daily returns are even stronger. To save space, we do not report the summary statistics on the 24 industry portfolios and the daily returns. They are available upon request.

\subsection{Estimating conditional covariances}

Under each currency denomination, we estimate the conditional covariance between excess returns on a (country-index or industry) portfolio $i$ and the global market portfolio $m$ using a bivariate GARCH specification:

$$
\begin{aligned}
& R_{i, t+1}=\alpha_{0}^{i}+\alpha_{1}^{i} R_{i, t}+\varepsilon_{i, t+1}, \\
& R_{m, t+1}=\alpha_{0}^{m}+\alpha_{1}^{m} R_{m, t}+\varepsilon_{m, t+1}, \\
& \mathbb{E}_{t}\left[\varepsilon_{i, t+1}^{2}\right] \equiv \sigma_{i, t+1}^{2}= \gamma_{0}^{i}+\gamma_{1}^{i} \varepsilon_{i, t}^{2}+\gamma_{2}^{i} \sigma_{i, t}^{2}, \\
& \mathbb{E}_{t}\left[\varepsilon_{m, t+1}^{2}\right] \equiv \sigma_{m, t+1}^{2}=\gamma_{0}^{m}+\gamma_{1}^{m} \varepsilon_{m, t}^{2}+\gamma_{2}^{m} \sigma_{m, t}^{2}, \\
& \mathbb{E}_{t}\left[\varepsilon_{i, t+1} \varepsilon_{m, t+1}\right] \equiv \sigma_{i m, t+1}=\gamma_{0}^{i m}+\gamma_{1}^{i m} \varepsilon_{i, t} \varepsilon_{m, t}+\gamma_{2}^{i m} \sigma_{i m, t},
\end{aligned}
$$


where $R_{i, t}$ and $R_{m, t}$ denote the time- $t$ excess returns on portfolio $i$ and the market portfolio $m$ over a riskfree rate, respectively. First, we use an $\operatorname{AR}(1)$ specification to demean the excess returns. Then we define each element of the conditional covariance matrix as a $\operatorname{GARCH}(1,1)$ process. With $\mathbb{E}_{t}[\cdot]$ denoting the conditional expectation operator, $\sigma_{i, t+1}^{2}, \sigma_{m, t+1}^{2}$, and $\sigma_{i m, t+1}$ denote the time- $t$ conditional forecasts of the return variance and covariance from time $t$ to time $t+1$. The GARCH specifications in equations (1) to (5) do not arise directly from the asset pricing model, but they provide a close and parsimonious approximation of the form of heteroscedasticity typically encountered with economic time-series data (Bollerslev, Engle, and Wooldridge (1988)). The specifications in equations (1) to (5) are direct multivariate generalizations of univariate GARCH models of Engle (1982) and Bollerslev (1986).

We estimate the multivariate GARCH specification by maximizing the likelihood function of the return innovations. The likelihood functions are often specified assuming normal return innovations, but given the strong evidence on stock return non-normalities, our estimation considers a more general distribution for the return innovation that accommodates return fat tails. We assume that the conditional distribution of the return innovation follows a bivariate Student- $t$ distribution. Using $\varepsilon_{t}$ and $\Sigma_{t}$ to denote the bivariate demeaned excess return vector and the conditional covariance matrix forecasts,

$$
\varepsilon_{t}=\left[\begin{array}{c}
R_{i, t}-\alpha_{0}^{i}-\alpha_{1}^{i} R_{i, t-1} \\
R_{m, t}-\alpha_{0}^{m}-\alpha_{1}^{m} R_{m, t-1}
\end{array}\right], \quad \Sigma_{t}=\left[\begin{array}{cc}
\sigma_{i, t}^{2} & \sigma_{i m, t} \\
\sigma_{i m, t} & \sigma_{m, t}^{2}
\end{array}\right]
$$

the bivariate Student- $t$ density is

$$
f\left(\varepsilon_{t} \mid \mathcal{F}_{t-1}\right)=\frac{\Gamma((v+2) / 2)}{\pi(v-2) \Gamma(v / 2)}\left|\Sigma_{t}\right|^{-1 / 2}\left(1+\frac{\varepsilon_{t}^{\top} \Sigma_{t}^{-1} \varepsilon_{t}}{v-2}\right)^{-(v+2) / 2}
$$

where $\mathcal{F}_{t-1}$ denotes the time $(t-1)$ filtration, $\Gamma($.$) denotes the gamma function, and v$ is the degree of freedom, which controls the tail behavior of the $t$-distribution. Thus, we can write the log-likelihood function as

$$
\mathcal{L}(\Theta)=-\frac{1}{2} \sum_{t=1}^{T}\left[2 \ln \frac{\pi(v-2) \Gamma(v / 2)}{\Gamma((v+2) / 2)}+\ln \left|\Sigma_{t}\right|+(v+2) \ln \left(1+\frac{\varepsilon_{t}^{\top} \Sigma_{t}^{-1} \varepsilon_{t}}{v-2}\right)\right]
$$

where $\Theta$ denotes the vector of parameters in the specifications (1) to (5) and $T$ denotes the number of monthly (or daily) observations for each series. Bollerslev (1987), Hsieh (1989a,b), and Nelson (1991), among others, use fat-tailed distributions such as the student- $t$ and the generalized error distributions in GARCH model estimations for stock returns and exchange rates. 
We also investigate whether country-specific risks are priced after controlling for the global market portfolio. For this purpose, we first regress returns on each country-specific portfolio $k$ on the global market portfolio,

$$
R_{k, t}=a+b R_{m, t}+E_{k, t}
$$

where both returns are denominated in country- $k$ currency and the regression residual $E_{k, t}$ captures the countryspecific risk that is orthogonal to the global market portfolio. Then, under each currency denomination $k$, we estimate the conditional covariance between each country-index or industry portfolio, $i$, with the countryspecific risk factor $E_{k, t}$ using an analogous bivariate GARCH specification. We label this covariance as $\omega_{i k, t}$.

We repeat the estimation procedure for each of the seven country-index portfolios and the 24 industry portfolios, and for each portfolio under each of the seven currency denominations, under both monthly and daily frequency, altogether 868 estimations. These estimations generate a large amount of parameter estimates and statistics. To save space, we only report some results for illustration. Appendix B reports the maximum likelihood estimates of $v$, the corresponding $t$-statistics, and the Wald test results for monthly returns on the country-index and world market portfolios. The Wald test is constructed under the null hypothesis of return normality: $1 / v=0$. As can be seen from the $p$-values of the Wald statistics, the null hypothesis of return normality is generally rejected in favor of the student $t$ distribution.

Appendix C presents the parameter estimates for the conditional covariances between monthly returns on the country-index portfolios and the global market portfolio under each of the seven currency denominations. The persistence of the conditional covariance dynamics on each series is measured by the sum of $\gamma_{1}^{i m}$ and $\gamma_{2}^{i m}$. The results indicate that the conditional covariances are highly persistent for portfolios on Japan, UK, US, and Canada. For example, the sum of $\gamma_{1}^{i m}$ and $\gamma_{2}^{i m}$ is in the range of 0.93 to 0.99 for Japan, and 0.94 to 0.98 for UK. The persistence estimates are lower for portfolios on Germany, France, and Italy. These patterns hold across all currency denominations.

\subsection{Estimating the intertemporal coefficients}

Given the conditional covariance estimates under each currency denomination, we estimate the intertemporal risk-return relations using the following set of simultaneous equations,

$$
R_{i, t+1}^{k}=C_{i}^{k}+A^{k} \sigma_{i m, t+1}^{k}+B^{k} \omega_{i k, t+1}+e_{t+1}^{k}, \quad i=1,2, \cdots, n,
$$


where $k$ denotes the currency denomination and $n$ denotes the number of portfolios and also the number of simultaneous equations in the estimation, which is seven when using country-index portfolios and 24 when using industry portfolios. In equation (10), we constrain the slope coefficients $\left(A^{k}, B^{k}\right)$ under each currency denomination to be the same across all $n$ portfolios for internal consistency. Nevertheless, we allow the intercept $C_{i}^{k}$ to differ across different portfolios. We use deviations of the intercept estimates from zero as a test against the validity and sufficiency of our risk-return specification. Furthermore, we allow all coefficients to differ under different currency denominations. From the different parameter estimates, we infer the pricing of exchange rate risk and the different risk preferences for investors in different economies.

We estimate the system of simultaneous equations using a weighted least square method that allows us to place constraints on coefficients across equations. We compute the $t$-statistics of the parameter estimates accounting for heteroskedasticity and autocorrelation as well as contemporaneous cross-correlations in the errors from different equations. The estimation methodology can be regarded as an extension of the seemingly unrelated regression method. Appendix $\mathrm{D}$ provides further details on the estimation.

To test the statistical significance of the differences between coefficient estimates under different currency denominations, we also pool all the estimated equations under different currency denominations together and estimate the covariance matrix of all the parameter estimates simultaneously, accounting for heteroskedasticity, autocorrelation, and contemporaneous cross-correlations in the errors from all the equations.

\section{Evidence from G7 country-index portfolios}

Under the assumption of financial integration, we first estimate the simple intertemporal relation between the country-index excess returns and their conditional covariance with the global index portfolio under each currency denomination $k$,

$$
R_{i, t+1}^{k}=C_{i}^{k}+A^{k} \sigma_{i m, t+1}^{k}+e_{t+1}^{k}, \quad i=1,2, \cdots, 7 .
$$

Table 1 reports the parameter estimates and the $t$-statistics under each of the seven currency denominations. The slope estimates $A^{k}$ are all positive and statistically significant, suggesting that the global risk factor is priced across the G7 countries. Nevertheless, the magnitudes of the estimates differ markedly under different currency denominations. The slope estimate is the highest at 7.21 under yen denomination, lowest at 3.23 under lira denomination. Broadly, we can classify the estimates into three geographic groups. Japan, as the representative of the Asian market, has investors that ask for the highest compensation for the same level of 
risk. Canada and the United States represent the North American market, which generates risk-return tradeoff estimates between five and six. Finally, the four European economies all generate slope estimates less than four. The different magnitudes suggest that the exchange rate is priced and that investors in different economic regions have different risk preferences.

[Insert Table 1 about here.]

The intercept estimates are all small and statistically insignificant regardless of currency denomination, suggesting that one global risk factor explains well the cross-sectional differences in country-index portfolio returns. The abnormal excess returns from each country portfolios are not statistically different from zero.

To gauge the statistical significance of the slope coefficient differences under different currency denominations, the last panel in Table 1 reports the $t$-statistics on pair-wise differences between the slope coefficient estimates. The statistics confirm our classification of the three broad economic regions. The coefficient estimate on yen is significantly higher than the coefficient estimates on all other currency denominations. The coefficient estimates under Canadian and US dollar denominations are significantly higher than the estimates from the four European currencies. On the other hand, the coefficient estimates between the two dollar denominations and the estimates among the four European currencies are not significantly different from one another.

To investigate whether country-specific risks are priced in addition to the global risk factor, we also estimate the following simultaneous equations:

$$
R_{i, t+1}^{k}=C_{i}^{k}+A^{k} \sigma_{i m, t+1}^{k}+B^{k} \omega_{i k, t+1}+e_{t+1}^{k}, \quad i=1,2, \cdots, 7,
$$

where $\omega_{i k, t}$ measures the conditional covariance between the country- $i$ portfolio excess return and the country$k$ residual risk factor. A significant estimate for the common slope $B^{k}$ would suggest that country-specific risks are also priced. Table 2 reports the results on (12) under each of the seven currency denominations. The slope estimates on the country-specific risk factors are not statistically significant under any of the seven currency denominations, suggesting that country-specific risks are not priced.

[Insert Table 2] about here.]

The estimates on $A^{k}$ are similar to those reported in Table 1 showing the robustness of the coefficient estimates. In particular, the ranking across different currency denominations remains about the same, with 
Japanese consumers asking the highest compensation, and Italian consumers the least, for the same level of risk. The $t$-statistics on the slope differences confirm the significance of the differences across the three economic regions.

Also similar to the results in Table 1, the abnormal returns are not significantly different from zero. The insignificance of the abnormal returns and the slope coefficient on the country-specific risk factors provide evidence that the financial markets among the G7 countries are integrated. Investors can invest globally with little additional cost. Nevertheless, the different slope estimates on the covariance with the global portfolio under different currency denominations reveal that consumers in different geographic areas are still limited to consume mainly in their local currencies. Consumption risk sharing is incomplete.

\section{Evidence from global industry portfolios}

With financial integration, we do not need to form country-specific portfolios in our investment, nor do we need to form country-specific portfolios in estimating the risk-return relation. It is the currency denomination that generates the different coefficient estimates, not how the portfolios are formed. In principle, any ways of forming portfolios should generate similar results for the risk-return relation. To emphasize this principle and to check the robustness of our findings, we re-estimate the risk-return relation using 24 global industry portfolios. The estimation proceeds analogously to that in the previous section except that now the system of simultaneous equations has 24 instead of seven equations.

Table 3 reports the common slope estimates from the global industry portfolios, as well as the $t$-statistics on the differences across different currency denominations. The first panel assumes financial integration and hence does not include the country-specific risk factors. The second panel allows for the country-specific risk factors in the estimation; nevertheless, the common slope estimates on the covariance with the country-specific risk factors are not statistically significant in any currency denominations. In contrast, the common slope estimates on the global market portfolio risk factor are strongly significant. More importantly, the common slope estimates on the global market portfolio differ across different currency denominations. The rankings of the estimates and the statistical significance of their differences are similar to those obtained from countryindex portfolios. The risk-return coefficient is the highest at about seven under yen denomination, around five under Canadian and US dollars, and below four under European currencies. We allow the intercepts to differ across different industry portfolios, but none of the intercept estimates are statistically significant. We do not report the intercept estimates to save space. 
[Insert Table 3 about here.]

\section{Robustness analysis}

For robustness check, we repeat the analysis by using daily returns and by considering different GARCH specifications for the conditional covariance estimations. The results are robust to these variations.

\subsection{Risk-return relations in daily frequency}

To investigate how the investment horizon affects the risk-return relation, we re-estimate the conditional covariances and the simultaneous equations in daily frequency. Table4 4 reports the common slope estimates with and without the country-specific risk factors, using both country-index portfolios and industry portfolios. The results are similar to those obtained from monthly returns. The slope coefficient estimates on the covariance with the global market portfolio are all strongly significant, but the estimates on the country-specific risk remain insignificant even with daily data. The intercept estimates are all insignificant and hence not reported. The risk-return coefficient estimates with respect to the global market portfolio maintain the same ranking across different currency denominations.

[Insert Table 4 about here.]

\subsection{Alternative GARCH specifications}

Since the conditional variance and covariance of stock market returns are not observable, different approaches and specifications used in estimating the conditional variance and covariance could lead to different conclusions. In the previous sections, we use the bivariate $\operatorname{GARCH}(1,1)$ specification in equations (1) to (5) to obtain conditional variance and covariance estimates. In this section, we consider an alternative specification that allows downward return movements and upward return movements to have different impacts on the conditional 
volatility forecasts:

$$
\begin{aligned}
R_{i, t+1} & =\alpha_{0}^{i}+\alpha_{1}^{i} R_{i, t}+\varepsilon_{i, t+1}, \\
R_{m, t+1} & =\alpha_{0}^{m}+\alpha_{1}^{m} R_{m, t}+\varepsilon_{m, t+1}, \\
\sigma_{i, t+1}^{2} & =\gamma_{0}^{i}+\gamma_{1}^{i} \varepsilon_{i, t}^{2}+\gamma_{2}^{i} \sigma_{i, t}^{2}+\gamma_{3}^{i} \varepsilon_{i, t}^{2} I_{i, t}^{-} \\
\sigma_{m, t+1}^{2} & =\gamma_{0}^{m}+\gamma_{1}^{m} \varepsilon_{m, t}^{2}+\gamma_{2}^{m} \sigma_{m, t}^{2}+\gamma_{3}^{m} \varepsilon_{m, t}^{2} I_{m, t}^{-}, \\
\sigma_{i m, t+1} & =\rho_{i m} \sigma_{i, t+1} \sigma_{m, t+1},
\end{aligned}
$$

where $I_{i, t}^{-}$is an indicator function that equals one when $\varepsilon_{i, t}$ is negative and zero otherwise. The indicator function generates an asymmetric GARCH effect between positive and negative shocks (Glosten, Jagannathan, and Runkle (1993)). The parameters in equations (13) to (17) are estimated by maximizing the log-likelihood function given in equation (8). The covariances between portfolio returns and country-specific risk factors are estimated analogously by replacing the global portfolio $R_{m}$ with the country- $k$ specific risk factor $E_{k}$.

We use the conditional covariances obtained from the above asymmetric GARCH specification to reestimate the system of simultaneous equations. Table 5 reports the slope estimates and $t$-statistics. The four panels represent four cases based on whether we use country-index portfolios or industry portfolios and on whether we include the country-specific risk factors. The estimates in the four panels yield the same conclusions as from our previous estimations. The common slope estimates $\left(A^{k}\right)$ on the covariance with the global market portfolio returns are all positive and statistically significant, but the magnitudes of the estimates differ considerably under different currency denominations. Again, we can classify the seven currencies into three broad economic regions, with the coefficient the highest under yen denomination, moderate under Canadian and US dollars, and the lowest under the European currencies. When the covariances with the country-specific risk factors are included, the slope estimates $\left(B^{k}\right)$ are all statistically insignificant, again evidence for international financial market integration. To save space, we do not report the intercept estimates, none of which are statistically significant.

[Insert Table 5]about here.] 


\section{Conclusion}

In this paper, we investigate the role of currency denomination in the intertemporal risk-return relation among industrialized countries. Similar to previous findings, our estimation shows that the financial markets of the industrialized countries are integrated. We obtain significant pricing coefficient estimates on the global index, but insignificant estimates on country-specific risk factors.

Different from the literature, however, we neither assume that purchasing power parity and uncovered interest rate parity hold, nor do we focus on the risk-return relation under one currency denomination such as the US dollar. Instead, the focus of our study is to analyze whether the risk-return tradeoff differs under different currency denominations. The answer to this question is affirmative. The risk-return coefficient is the largest at around seven when the returns are denominated in Japanese yen, the smallest at around three to four when the returns are denominated in European currencies, and in the middle at about five to six when the returns are denominated in the Canadian or US dollars. The estimates stay in the same range and the rankings remain the same when we replace country equity indices with industry portfolios in estimating the intertemporal relations, when we change the return frequency from monthly to daily, and when we consider different specifications for the conditional covariance process, suggesting that our findings are robust.

The different risk-return coefficient estimates illustrate that the exchange rate risk is priced, and that although the international financial markets are integrated, significant segmentation remains in the international goods market. Investors can invest globally, but they are mostly constrained to consume locally. Therefore, we can identify the risk preference differences for the world market portfolio across different economies by exploiting the information content in the exchange rates. Our study shows that exchange rate dynamics are neither exogenously given, nor tangential to asset pricing, but rather very informative about the pricing differences of the global market portfolio across different economies. 


\section{Appendix A. Summary statistics of portfolio returns}

This table presents the mean, standard deviation, skewness, excess kurtosis, and the Jarque-Bera (JB) statistics of monthly excess returns, in annualized percentages, on the country and world portfolios under each of the seven currency denominations. The excess return is computed as the difference between the index return in a currency denomination and the short-term riskfree rate in that currency. Data are from January 1970 to December 2004.

\begin{tabular}{|c|c|c|c|c|c|c|c|c|}
\hline Country & Statistics & Yen & C. Dollar & Dollar & Mark & Pound & Franc & Lira \\
\hline \multirow[t]{5}{*}{ Japan } & Mean & 3.32 & 3.05 & 4.61 & 3.20 & 2.70 & 5.32 & 3.29 \\
\hline & Std & 18.38 & 22.10 & 22.29 & 22.09 & 22.03 & 22.02 & 22.23 \\
\hline & Skewness & -0.28 & 0.05 & 0.01 & -0.07 & -0.08 & -0.11 & -0.07 \\
\hline & Kurtosis & 1.30 & 0.72 & 0.42 & 0.62 & 0.40 & 0.67 & 0.47 \\
\hline & JB & 35.07 & 9.29 & 3.13 & 7.05 & 3.29 & 8.88 & 4.13 \\
\hline \multirow[t]{5}{*}{ Canada } & Mean & 2.42 & 2.15 & 3.71 & 2.30 & 1.80 & 4.43 & 2.39 \\
\hline & Std & 21.63 & 17.34 & 19.41 & 21.87 & 20.94 & 21.39 & 21.45 \\
\hline & Skewness & -0.61 & -0.79 & -0.82 & -0.54 & -0.76 & -0.50 & -0.44 \\
\hline & Kurtosis & 2.41 & 2.94 & 2.86 & 1.82 & 2.57 & 1.78 & 1.74 \\
\hline & $\mathrm{JB}$ & 127.93 & 195.78 & 190.42 & 78.88 & 155.76 & 73.25 & 66.96 \\
\hline \multirow[t]{5}{*}{$\overline{\text { US }}$} & Mean & 2.98 & 2.71 & 4.27 & 2.86 & 2.36 & 4.98 & 2.95 \\
\hline & Std & 19.11 & 15.13 & 15.59 & 19.28 & 18.71 & 18.93 & 19.01 \\
\hline & Skewness & -0.57 & -0.51 & -0.58 & -0.70 & -0.65 & -0.62 & -0.46 \\
\hline & Kurtosis & 2.14 & 2.29 & 2.40 & 2.28 & 2.41 & 1.89 & 2.06 \\
\hline & JB & 102.91 & 110.08 & 124.98 & 125.30 & 131.45 & 89.04 & 88.99 \\
\hline \multirow[t]{5}{*}{ Germany } & Mean & 2.83 & 2.56 & 4.11 & 2.70 & 2.20 & 4.83 & 2.79 \\
\hline & Std & 22.28 & 21.20 & 21.61 & 20.08 & 21.24 & 20.47 & 20.83 \\
\hline & Skewness & -0.42 & -0.44 & -0.51 & -0.76 & -0.65 & -0.69 & -0.56 \\
\hline & Kurtosis & 1.63 & 1.39 & 1.82 & 3.04 & 2.69 & 2.63 & 2.31 \\
\hline & JB & 58.53 & 47.45 & 76.53 & 202.76 & 156.47 & 154.53 & 115.34 \\
\hline \multirow[t]{5}{*}{ UK } & Mean & 3.89 & 3.62 & 5.18 & 3.77 & 3.27 & 5.89 & 3.86 \\
\hline & Std & 22.71 & 21.76 & 22.19 & 22.60 & 20.20 & 21.84 & 22.69 \\
\hline & Skewness & 0.17 & 0.54 & 0.46 & 0.01 & 0.25 & 0.10 & 0.04 \\
\hline & Kurtosis & 5.10 & 6.63 & 5.82 & 5.42 & 8.60 & 5.44 & 5.98 \\
\hline & JB & 458.83 & 791.85 & 608.28 & 516.08 & 1302.73 & 519.41 & 626.41 \\
\hline \multirow[t]{5}{*}{ France } & Mean & 3.73 & 3.46 & 5.01 & 3.60 & 3.11 & 5.73 & 3.69 \\
\hline & Std & 22.55 & 22.23 & 22.66 & 21.59 & 22.09 & 20.75 & 21.96 \\
\hline & Skewness & -0.33 & -0.27 & -0.36 & -0.32 & -0.31 & -0.35 & -0.28 \\
\hline & Kurtosis & 0.98 & 1.62 & 1.55 & 1.25 & 1.92 & 1.22 & 1.21 \\
\hline & JB & 24.60 & 51.01 & 51.36 & 34.78 & 71.41 & 34.87 & 31.35 \\
\hline \multirow{5}{*}{ Italy } & Mean & -0.02 & -0.29 & 1.27 & -0.15 & -0.64 & 1.98 & -0.05 \\
\hline & Std & 26.04 & 25.06 & 25.40 & 25.98 & 25.32 & 25.60 & 23.84 \\
\hline & Skewness & -0.09 & 0.10 & -0.03 & 0.01 & 0.20 & 0.13 & 0.17 \\
\hline & Kurtosis & 0.52 & 0.64 & 0.62 & 1.05 & 0.48 & 0.72 & 0.75 \\
\hline & JB & 5.29 & 7.94 & 6.80 & 19.33 & 6.90 & 10.40 & 11.82 \\
\hline \multirow[t]{5}{*}{ World } & Mean & 2.72 & 2.45 & 4.01 & 2.60 & 2.10 & 4.73 & 2.69 \\
\hline & Std & 15.69 & 13.99 & 14.62 & 16.44 & 15.79 & 16.10 & 16.41 \\
\hline & Skewness & -0.79 & -0.50 & -0.62 & -0.75 & -0.84 & -0.72 & -0.52 \\
\hline & Kurtosis & 2.39 & 1.42 & 1.65 & 1.97 & 2.38 & 1.65 & 1.93 \\
\hline & JB & 143.61 & 52.69 & 75.30 & 107.64 & 148.86 & 83.70 & 84.32 \\
\hline
\end{tabular}




\section{Appendix B. Maximum likelihood estimates on the tail-thickness parameter of the Student- $t$ distribution}

In the following table, for each country, the first row reports the maximum likelihood estimates of the tail-thickness parameter $v$ for the Student $t$ distribution for each country and global market portfolio returns under each of the seven currency denominations. The second row reports the corresponding $t$-statistics of the estimates in parentheses. The third row reports the Wald statistics with the null hypothesis: $1 / v=0$, which is a test of normality for the return distribution. The fourth row gives the $p$-values of the Wald statistics in parentheses. The estimation is based on monthly returns (in percentages) from January 1970 to December 2004.

\begin{tabular}{|c|c|c|c|c|c|c|c|c|}
\hline Country & Statistics & Yen & C. Dollar & Dollar & Mark & Pound & Franc & Lira \\
\hline \multirow[t]{4}{*}{ Japan } & Estimates & 6.3888 & 15.4366 & 26.9978 & 11.1130 & 14.9202 & 12.0571 & 14.4569 \\
\hline & $t$-values & $(2.96)$ & ( 1.30$)$ & $(0.67)$ & ( 1.90 ) & ( 1.20$)$ & ( 1.88$)$ & ( 1.54$)$ \\
\hline & Wald test & 8.7766 & 1.6852 & 0.4518 & 3.6254 & 1.4339 & 3.5181 & 2.3726 \\
\hline & $p$-values & $(0.00)$ & $(0.19)$ & $(0.50)$ & $(0.06)$ & $(0.23)$ & $(0.06)$ & $(0.12)$ \\
\hline \multirow[t]{4}{*}{ Canada } & Estimates & 5.9192 & 6.1275 & 5.4675 & 8.1430 & 6.5392 & 7.8944 & 7.4976 \\
\hline & $t$-values & $(3.65)$ & ( 4.09 ) & ( 3.92 ) & ( 3.33 ) & (3.81) & $(3.27)$ & (3.32) \\
\hline & Wald test & 13.2930 & 16.7253 & 15.3841 & 11.0724 & 14.5356 & 10.6826 & 11.0522 \\
\hline & $p$-values & $(0.00)$ & $(0.00)$ & $(0.00)$ & $(0.00)$ & $(0.00)$ & $(0.00)$ & $(0.00)$ \\
\hline \multirow[t]{4}{*}{ US } & Estimates & 6.5241 & 8.2923 & 6.9545 & 6.3356 & 6.6194 & 6.9381 & 5.2314 \\
\hline & $t$-values & ( 3.74 ) & (3.66) & (3.72) & ( 4.02 ) & ( 4.02 ) & ( 3.70$)$ & ( 3.90$)$ \\
\hline & Wald test & 13.9666 & 13.4164 & 13.8448 & 16.1837 & 16.1766 & 13.6635 & 15.1796 \\
\hline & $p$-values & $(0.00)$ & $(0.00)$ & $(0.00)$ & $(0.00)$ & $(0.00)$ & $(0.00)$ & $(0.00)$ \\
\hline \multirow[t]{4}{*}{ Germany } & Estimates & 8.3728 & 6.4173 & 6.4108 & 6.4647 & 6.1177 & 6.0007 & 6.5277 \\
\hline & $t$-values & $(2.48)$ & ( 2.95 ) & ( 2.88$)$ & (3.19) & ( 3.34 ) & ( 3.36 ) & ( 3.07$)$ \\
\hline & Wald test & 6.1606 & 8.7209 & 8.3120 & 10.1480 & 11.1825 & 11.2731 & 9.4371 \\
\hline & $p$-values & $(0.01)$ & $(0.00)$ & $(0.00)$ & $(0.00)$ & $(0.00)$ & $(0.00)$ & $(0.00)$ \\
\hline \multirow[t]{4}{*}{ UK } & Estimates & 6.9682 & 6.5172 & 6.0979 & 5.3958 & 5.0589 & 5.3416 & 5.1642 \\
\hline & $t$-values & ( 3.64 ) & ( 3.64 ) & ( 3.50$)$ & $(4.45)$ & ( 4.72 ) & ( 4.45$)$ & $(4.47)$ \\
\hline & Wald test & 13.2805 & 13.2316 & 12.2156 & 19.8045 & 22.3110 & 19.8233 & 19.9458 \\
\hline & $p$-values & $(0.00)$ & $(0.00)$ & $(0.00)$ & $(0.00)$ & $(0.00)$ & $(0.00)$ & $(0.00)$ \\
\hline \multirow[t]{4}{*}{ France } & Estimates & 10.2321 & 7.1106 & 6.8773 & 9.6968 & 6.7369 & 11.5376 & 9.0810 \\
\hline & $t$-values & $(2.41)$ & $(2.80)$ & ( 2.63 ) & $(2.86)$ & (3.28) & $(2.41)$ & $(2.58)$ \\
\hline & Wald test & 5.7997 & 7.8618 & 6.9138 & 8.1932 & 10.7906 & 5.8215 & 6.6793 \\
\hline & $p$-values & $(0.02)$ & $(0.01)$ & $(0.01)$ & $(0.00)$ & $(0.00)$ & $(0.02)$ & $(0.01)$ \\
\hline \multirow[t]{4}{*}{ Italy } & Estimates & 10.6516 & 12.2473 & 11.0756 & 6.6932 & 15.2156 & 9.5763 & 10.8801 \\
\hline & $t$-values & $(1.69)$ & ( 1.70$)$ & ( 1.85 ) & ( 2.60$)$ & $(1.25)$ & $(1.67)$ & $(1.50)$ \\
\hline & Wald test & 2.8588 & 2.8785 & 3.4080 & 6.7478 & 1.5692 & 2.7749 & 2.2489 \\
\hline & $p$-values & $(0.09)$ & $(0.09)$ & $(0.06)$ & $(0.01)$ & $(0.21)$ & $(0.10)$ & $(0.13)$ \\
\hline \multirow[t]{4}{*}{ World } & Estimates & 5.8358 & 8.8898 & 5.9330 & 6.8865 & 6.6998 & 6.9954 & 5.4591 \\
\hline & $t$-values & ( 3.91$)$ & (2.96) & ( 3.58 ) & (3.62) & (3.94) & $(3.55)$ & ( 4.15 ) \\
\hline & Wald test & 15.2906 & 8.7578 & 12.8184 & 13.1096 & 15.5205 & 12.6098 & 17.2610 \\
\hline & $p$-values & $(0.00)$ & $(0.00)$ & $(0.00)$ & $(0.00)$ & $(0.00)$ & $(0.00)$ & $(0.00)$ \\
\hline
\end{tabular}




\section{Appendix C. Maximum likelihood estimates of the conditional covariances}

The following table reports the maximum likelihood estimates of the parameters that govern the dynamics of the conditional covariance between the excess returns on country-index portfolios and global market portfolios,

$$
\sigma_{i m, t+1}=\gamma_{0}^{i m}+\gamma_{1}^{i m} \varepsilon_{i, t} \varepsilon_{m, t}+\gamma_{2}^{i m} \sigma_{i m, t},
$$

for the G7 countries under each of the seven currency denominations. The $t$-statistics are in parentheses. The estimation is based on monthly returns (in percentages) from January 1970 to December 2004.

\begin{tabular}{|c|c|c|c|c|c|c|c|c|c|c|c|c|c|c|c|}
\hline \multirow[t]{2}{*}{ Country } & \multirow{2}{*}{$\frac{\text { Estimates }}{\gamma_{0}^{i m}}$} & \multicolumn{2}{|c|}{ Yen } & \multicolumn{2}{|c|}{ C. Dollar } & \multicolumn{2}{|c|}{ Dollar } & \multicolumn{2}{|c|}{ Mark } & \multicolumn{2}{|c|}{ Pound } & \multicolumn{2}{|c|}{ Franc } & \multicolumn{2}{|c|}{ Lira } \\
\hline & & 0.0002 & $(2.03)$ & 0.0003 & $(2.11)$ & 0.0001 & $(1.85)$ & 0.0001 & $(1.97)$ & 0.0003 & $(2.31)$ & 0.0001 & $(1.88)$ & 0.0001 & $(1.93)$ \\
\hline \multirow[t]{3}{*}{ Japan } & $\gamma_{1}^{i m}$ & 0.0383 & ( 2.92 ) & 0.0395 & ( 3.40$)$ & 0.0165 & ( 2.17$)$ & 0.0151 & $(2.83)$ & 0.0154 & ( 3.24$)$ & 0.0113 & $(2.79)$ & 0.0143 & $(2.62)$ \\
\hline & $\gamma_{2}^{i m}$ & 0.9529 & $(48.54)$ & 0.9432 & ( 39.87$)$ & 0.9563 & ( 49.79$)$ & 0.9634 & $(41.44)$ & 0.9311 & ( 46.91$)$ & 0.9456 & $(50.12)$ & 0.9196 & $(47.91)$ \\
\hline & $\gamma_{0}^{i m}$ & 0.0006 & $(3.09)$ & 0.0002 & $(2.20)$ & 0.0002 & $(2.42)$ & 0.0002 & $(2.02)$ & 0.0003 & $(2.32)$ & 0.0003 & $(2.58)$ & 0.0004 & $(2.06)$ \\
\hline \multirow[t]{3}{*}{ Canada } & $\gamma_{1}^{i m}$ & 0.0467 & $(2.15)$ & 0.0552 & $(2.34)$ & 0.0599 & $(2.74)$ & 0.0505 & (3.09) & 0.0494 & ( 3.01$)$ & 0.0608 & ( 3.94$)$ & 0.0491 & ( 3.83 ) \\
\hline & $\gamma_{2}^{i m}$ & 0.6931 & ( 6.93$)$ & 0.8165 & ( 11.01$)$ & 0.8150 & $(12.56)$ & 0.8456 & $(10.71)$ & 0.8223 & ( 13.99 ) & 0.8104 & $(16.70)$ & 0.8305 & $(14.57)$ \\
\hline & $\gamma_{0}^{i m}$ & 0.0001 & $(2.46)$ & 0.0001 & $(4.36)$ & 0.0001 & $(4.57)$ & 0.0001 & $(3.05)$ & 0.0001 & $(2.85)$ & 0.0001 & $(2.84)$ & 0.0001 & $(2.47)$ \\
\hline \multirow[t]{3}{*}{ US } & $\gamma_{1}^{i m}$ & 0.0123 & ( 3.37 ) & 0.0791 & ( 5.31$)$ & 0.0807 & ( 4.61$)$ & 0.0480 & ( 5.33$)$ & 0.0612 & ( 4.13 ) & 0.0653 & ( 5.23$)$ & 0.0568 & ( 5.38$)$ \\
\hline & $\gamma_{2}^{i m}$ & 0.9625 & ( 70.22 ) & 0.8504 & ( 35.86$)$ & 0.8237 & $(32.26)$ & 0.8813 & (30.99) & 0.8640 & ( 29.87 ) & 0.8901 & $(31.25)$ & 0.8754 & (27.09) \\
\hline & $\gamma_{0}^{i m}$ & 0.0007 & $(3.93)$ & 0.0005 & $(1.85)$ & 0.0003 & $(1.87)$ & 0.0005 & $(2.04)$ & 0.0004 & $(1.92)$ & 0.0004 & $(2.21)$ & 0.0005 & $(1.94)$ \\
\hline \multirow[t]{3}{*}{ Germany } & $\gamma_{1}^{i m}$ & 0.0367 & $(4.86)$ & 0.0774 & $(2.11)$ & 0.0940 & $(2.79)$ & 0.1003 & ( 4.97$)$ & 0.0810 & $(3.00)$ & 0.0876 & $(3.46)$ & 0.0930 & ( 3.12 ) \\
\hline & $\gamma_{2}^{i m}$ & 0.6392 & ( 6.39$)$ & 0.6122 & ( 6.34 ) & 0.6435 & ( 6.93$)$ & 0.6943 & ( 8.34$)$ & 0.6782 & $(7.31)$ & 0.6889 & $(7.90)$ & 0.6533 & ( 7.91$)$ \\
\hline & $\gamma_{0}^{i m}$ & 0.0001 & $(2.68)$ & 0.0001 & $(2.75)$ & 0.0001 & $(2.50)$ & 0.0001 & $(2.94)$ & 0.0001 & $(2.84)$ & 0.0001 & $(2.30)$ & 0.0001 & $(2.78)$ \\
\hline \multirow[t]{3}{*}{ UK } & $\gamma_{1}^{i m}$ & 0.0196 & ( 3.11$)$ & 0.0276 & ( 4.35$)$ & 0.0264 & ( 4.06$)$ & 0.0182 & ( 3.07 ) & 0.0276 & ( 3.94$)$ & 0.0151 & ( 3.31$)$ & 0.0248 & (3.26) \\
\hline & $\gamma_{2}^{i m}$ & 0.9307 & (39.21) & 0.9502 & $(46.31)$ & 0.9536 & $(80.54)$ & 0.9557 & $(68.21)$ & 0.9463 & $(65.82)$ & 0.9656 & $(87.71)$ & 0.9497 & (69.05) \\
\hline & $\gamma_{0}^{i m}$ & 0.0001 & $(2.57)$ & 0.0006 & $(2.30)$ & 0.0004 & $(2.00)$ & 0.0003 & $(1.81)$ & 0.0005 & $(1.98)$ & 0.0005 & $(1.79)$ & 0.0002 & $(2.09)$ \\
\hline \multirow[t]{3}{*}{ France } & $\gamma_{1}^{i m}$ & 0.0478 & ( 3.04 ) & 0.0911 & (3.21) & 0.0853 & ( 3.12 ) & 0.0698 & ( 3.12 ) & 0.0744 & $(2.95)$ & 0.0703 & $(2.60)$ & 0.0682 & (3.22) \\
\hline & $\gamma_{2}^{i m}$ & 0.6201 & ( 6.10$)$ & 0.6312 & ( 6.66 ) & 0.6501 & $(7.10)$ & 0.6389 & $(7.54)$ & 0.6579 & $(6.23)$ & 0.6411 & ( 6.48$)$ & 0.6627 & ( 6.43$)$ \\
\hline & $\gamma_{0}^{i m}$ & 0.0002 & $(2.48)$ & 0.0007 & $(2.41)$ & 0.0002 & $(1.91)$ & 0.0003 & $(1.90)$ & 0.0003 & $(2.31)$ & 0.0004 & $(2.00)$ & 0.0005 & $(1.82)$ \\
\hline \multirow[t]{2}{*}{ Italy } & $\gamma_{1}^{i m}$ & 0.0392 & $(3.14)$ & 0.1012 & ( 4.22 ) & 0.0787 & $(2.80)$ & 0.0831 & $(3.05)$ & 0.0992 & ( 3.56$)$ & 0.0735 & $(2.97)$ & 0.0603 & ( 3.11$)$ \\
\hline & $\gamma_{2}^{i m}$ & 0.6007 & $(6.00)$ & 0.6100 & ( 6.81$)$ & 0.6780 & $(7.04)$ & 0.6739 & ( 8.16$)$ & 0.6111 & $(7.77)$ & 0.6671 & $(7.03)$ & 0.6890 & ( 8.06 ) \\
\hline
\end{tabular}




\section{Appendix D. Estimation of a system of simultaneous equations}

Consider a system of $n$ simultaneous equations, of which the typical $i$ th equation is

$$
y_{i}+X_{i} \beta_{i}+u_{i}
$$

where $y_{i}$ is a $N \times 1$ vector of time-series observations on the $i$ th dependent variable, $X_{i}$ is a $N \times k_{i}$ matrix of observations of $k_{i}$ independent variables, $\beta_{i}$ is a $k_{i} \times 1$ vector of unknown regression coefficients to be estimated, and $u_{i}$ is a $N \times 1$ vector of random disturbance terms with mean zero. Parks (1967) proposes an estimation procedure that allows the error term to be both serially and cross-sectionally correlated. He assumes:

$$
u_{i t}=\rho_{i} u_{i t-1}+\varepsilon_{i t}, \quad\left|\rho_{i}\right|<1,
$$

where $\varepsilon_{i t}$ are zero-mean random variables satisfying the conditions:

$$
\begin{aligned}
& \mathbb{E}\left(\varepsilon_{i t} \varepsilon_{j t}^{\top}\right)=\sigma_{i j}, \quad i, j=1, \cdots, n ; \quad t=1, \cdots, N \\
& \mathbb{E}\left(\varepsilon_{i t} \varepsilon_{j s}\right)=0, \quad i, j=1, \cdots, n ; \quad s, t=1, \cdots, N, \quad \text { and } s \neq t
\end{aligned}
$$

Equation (D1) can then be written as

$$
y_{i}=X_{i} \beta_{i}+P_{i} \varepsilon_{i}
$$

with $u_{i}=P_{i} \varepsilon_{i}$, where $\varepsilon_{i}$ is a $N \times 1$ random vector with $\mathbb{E}\left(\varepsilon_{i} \varepsilon_{i}^{\top}\right)=\sigma_{i i} I$ and

$$
P_{i}=\left[\begin{array}{ccccc}
\left(1-\rho_{i}^{2}\right)-1 / 2 & 0 & 0 & \cdots & 0 \\
\rho_{i}\left(1-\rho_{i}^{2}\right)-1 / 2 & 1 & 0 & \cdots & 0 \\
\rho_{i}^{2}\left(1-\rho_{i}^{2}\right)-1 / 2 & \rho_{i} & 1 & \cdots & 0 \\
\vdots & & & & \\
\rho_{i}^{N-1}\left(1-\rho_{i}^{2}\right)-1 / 2 & \rho^{N-2} & \rho^{N-3} & \cdots & 1
\end{array}\right]
$$

Under this setup, Parks presents a consistent and asymptotically efficient three-step estimation technique for the regression coefficients. The first step uses single equation regressions to estimate the parameters of autoregressive model. The second step uses single equation regressions on transformed equations to estimate the contemporaneous covariances. Finally, the Aitken estimator is formed using the estimated covariance,

$$
\widehat{b}=\left(X^{\top} \Omega^{-1} X\right)^{-1} X^{\top} \Omega^{-1} y
$$

where $\Omega \equiv \mathbb{E}\left[u u^{\top}\right]$ denotes the general covariance matrix of the innovation. 


\section{References}

Backus, D., Foresi, S., Telmer, C., 2001. Affine term structure models and the forward premium anomaly. Journal of Finance 56, 279-304.

Backus, D. K., Gregory, A. W., Telmer, C. I., 1993. Accounting for forward rates in markets for foreign currency. Journal of Finance 48, 1887-1908.

Baillie, R. T., DeGennaro, R. P., 1990. Stock returns and volatility. Journal of Financial and Quantitative Analysis 25, 203-214.

Bakshi, G., Naka, A., 1997. On the unbiasedness of forward exchange rates. Finanical Review 32, 145-162.

Bali, T., 2008. The intertemporal relation between expected returns and risk. Journal of Financial Economics 87, 101131.

Bansal, R., 1997. An exploration of the forward premium puzzle in currency markets. Review of Financial Studies 10, 369-403.

Bansal, R., Dahlquist, M., 2000. The forward premium puzzle: Different tales from developed and emerging economies. Journal of International Economics 51, 115-144.

Bekaert, G., 1995. The time-variation of expected returns and volatility in foreign exchange markets. Journal of Business and Economic Statistics 13, 397-408.

Bekaert, G., Harvey, C., 1995. Time-varying world market integration. Journal of Finance 50, 403-444.

Bekaert, G., Hodrick, R. J., 1992. Characterizing predictable components in excess returns on equity and foreign exchange markets. Journal of Finance 47, 467-509.

Bollerslev, T., 1986. Generalized autoregressive conditional heteroskedasticity. Journal of Econometrics 31, 307-327.

Bollerslev, T., 1987. A conditionally heteroscedastic time series model for security prices and rates of return data. Review of Economics and Statistics 69, 542-547.

Bollerslev, T., Engle, R. F., Wooldridge, J. M., 1988. A capital asset pricing model with time-varying covariances. Journal of Political Economy 96, 116-131.

Bollerslev, T., Zhou, H., 2006. Volatility puzzles: A simple framework for gauging return-volatility regressions. Journal of Econometrics 131, 123-150.

Brandt, M. W., Kang, Q., 2004. On the relationship between the conditional mean and volatility of stock returns: A latent VAR approach. Journal of Financial Economics forthcoming.

Campbell, J. Y., 1987. Stock returns and the term structure. Journal of Financial Economics 18, 373-399. 
Campbell, J. Y., Hentschel, L., 1992. No news is good news: An asymmetric model of changing volatility in stock returns. Journal of Financial Economics 31, 281-318.

Cavaglia, S., Hodrick, R., Vadim, M., Zhang, X., 2002. Pricing the global industry portfolios. NBER Working Paper 9344 Columbia University.

Chan, K. C., Karolyi, G. A., Stulz, R. M., 1992. Global financial markets and the risk premium on U.S. equity. Journal of Financial Economics 32, 137-167.

Chou, R. Y., 1988. Volatility persistence and stock valuations: Some empirical evidence using GARCH. Journal of Applied Econometrics 3, 279-294.

Chou, R. Y., Engle, R., Kane, A., 1992. Measuring risk aversion from excess returns on a stock index. Journal of Econometrics 52, 201-224.

De Santis, G., Gerard, B., 1997. International asset pricing and portfolio diversification with time-varying risk. Journal of Finance 52, 1881-1912.

Dumas, B., Solnik, B., 1995. The world price of foreign exchage risk. Journal of Finance 50, 445-479.

Engel, C., 1996. The forward discount anomaly and the risk premium: A survey of recent evidence. Journal of Empirical Finance 3, 123-191.

Engle, R. F., 1982. Autoregressive conditional heteroskedasticity with estimates of the variance of U.K. inflation. Econometrica 50, 987-1008.

Ferson, W. E., Harvey, C. R., 1993. The risk and predictability of international equity returns. Review of Financial Studies 6, 527-566.

Flood, R., Rose, A., 1996. Fixes: Of the forward discount puzzle. Review of Economics and Statistics 78, 748-752.

French, K. R., Schwert, G. W., Stambaugh, R., 1987. Expected stock returns and volatility. Journal of Financial Economics 19, 3-29.

Ghyselsa, E., Santa-Clarab, P., Valkanov, R., 2005. There is a risk-return trade-off after all. Journal of Financial Economics 76, 509-548.

Glosten, L. R., Jagannathan, R., Runkle, D. E., 1993. On the relation between the expected value and the volatility of the nominal excess returns on stocks. Journal of Finance 48, 1779-1801.

Goyal, A., Santa-Clara, P., 2003. Idiosyncratic risk matters!. Journal of Finance 58, 975-1008.

Grauer, F. L. A., Litzenberger, R. H., Stehle, R. E., 1976. Sharing rules and equilibrium in an international capital market under uncertainty. Journal of Financial Economics 3, 233-256.

Guo, H., Whitelaw, R., 2006. Uncovering the risk-return relation in the stock market. Journal of Finance 61, 1433-1463. 
Harvey, C. R., 1989. Time-varying conditional covariances in tests of asset pricing models. Journal of Financial Economics 24, 289-317.

Harvey, C. R., 1991. The world price of covariance risk. Journal of Finance 46, 111-157.

Harvey, C. R., 2001. The specification of conditional expectations. Journal of Empirical Finance 8, 573-637.

Hodrick, R., 1987. The Empirical Evidence on the Efficiency of Forward and Futures Foreign Exchange Markets. Harwood Academic Publishers, New York.

Hsieh, D. A., 1984. Tests of rational expectations and no risk premium in forward exchange markets. Journal of International Economics 17, 173-184.

Hsieh, D. A., 1989a. Modeling heteroskedasticity in daily foreign exchange rates. Journal of Business and Economic Statistics 7, 307-317.

Hsieh, D. A., 1989b. Testing for nonlinear dependence in daily foreign exchange rates. Journal of Business 62, 339-368.

Merton, R. C., 1973. An intertemporal asset pricing model. Econometrica 41, 867-887.

Mishkin, F. S., 1984. Are real interest rates equal across countries? an empirical investigation of international parity conditions. Journal of Finance 39, 1345-1357.

Nelson, D. B., 1991. Conditional heteroskedasticity in asset returns: A new approach. Econometrica 59, 347-370.

Parks, R. W., 1967. Efficient estimation of a system of regression equations when disturbances are both serially and contemporaneously correlated. Journal of the American Statistical Association 62, 500-509.

Rogoff, K., 1996. The purchasing power parity puzzle. Journal of Economic Literature 34, 647-668.

Scruggs, J. T., 1998. Resolving the puzzling intertemporal relation between the market risk premium and conditional market variance: A two-factor approach. Journal of Finance 53, 575-603.

Sercu, P., 2003. A generalization of the international asset pricing model. In: Karolyi, G. A., Stulz, R. (Eds.), International Capital Markets. Edward Elgar Publishing Limited, Originally published in Revue de l'Association Franaise de Finance, 1980, 1(1), 91-135.

Solnik, B. H., 1974. An equilibrium model of the international capital market. Journal of Economic Theory 8, 500-524.

Whitelaw, R. F., 1994. Time variations and covariations in the expectation and volatility of stock market returns. Journal of Finance 49, 515-541. 
Table 1

The risk-return relation under different currency denominations

Entries report the estimates and $t$-statistics (in parentheses) of the following simultaneous equations under each currency denominations,

$$
R_{i, t+1}^{k}=C_{i}^{k}+A^{k} \sigma_{i m, t+1}^{k}+e_{i, t+1}^{k}, \quad i=1,2, \cdots, 7
$$

for $k=1, \cdots, 7$, where $R_{i, t+1}^{k}$ denotes the excess return in the country- $i$ index portfolio denominated in the $k$ th currency, and $\sigma_{i m, t+1}^{k}$ denotes the time- $t$ forecast of the conditional covariance between $R_{i, t+1}^{k}$ and $R_{m, t+1}^{k}$, the excess return on the market portfolio. The estimation is based on monthly returns (in percentages) from January 1970 to December 2004. We also report in the last panel the $t$-statistics on the pair-wise differences between the slope estimates $\left(A^{k}-A^{i}\right)$ under different currency denominations.

\begin{tabular}{|c|c|c|c|c|c|c|c|}
\hline Currency & Yen & C. Dollar & Dollar & Mark & Pound & Franc & Lira \\
\hline \multicolumn{8}{|c|}{ Common slopes: } \\
\hline$\overline{A^{k}}$ & $\begin{array}{l}7.2122 \\
(2.53) \\
\end{array}$ & $\begin{array}{l}5.7460 \\
(2.51) \\
\end{array}$ & $\begin{array}{l}5.0346 \\
(2.65) \\
\end{array}$ & $\begin{array}{l}3.7301 \\
(2.22) \\
\end{array}$ & $\begin{array}{r}3.7279 \\
(2.49) \\
\end{array}$ & $\begin{array}{r}3.6884 \\
(2.40) \\
\end{array}$ & $\begin{array}{l}3.2333 \\
(2.31) \\
\end{array}$ \\
\hline \multicolumn{8}{|c|}{ Intercepts: $C_{i}^{k}$} \\
\hline Japan & $\begin{array}{l}-0.0030 \\
(-0.69)\end{array}$ & $\begin{array}{l}-0.0092 \\
(-1.41)\end{array}$ & $\begin{array}{l}-0.0068 \\
(-1.28)\end{array}$ & $\begin{array}{l}-0.0119 \\
(-1.58)\end{array}$ & $\begin{array}{l}-0.0075 \\
(-1.31)\end{array}$ & $\begin{array}{l}0.0015 \\
(0.23)\end{array}$ & $\begin{array}{l}-0.0039 \\
(-0.70)\end{array}$ \\
\hline Canada & $\begin{array}{l}-0.0086 \\
(-1.20)\end{array}$ & $\begin{array}{l}-0.0065 \\
(-1.50)\end{array}$ & $\begin{array}{l}-0.0074 \\
(-1.47)\end{array}$ & $\begin{array}{l}-0.0150 \\
(-1.77)\end{array}$ & $\begin{array}{l}-0.0098 \\
(-1.56)\end{array}$ & $\begin{array}{l}-0.0010 \\
(-0.14)\end{array}$ & $\begin{array}{l}-0.0058 \\
(-0.95)\end{array}$ \\
\hline US & $\begin{array}{l}-0.0079 \\
(-1.13)\end{array}$ & $\begin{array}{l}-0.0069 \\
(-1.53)\end{array}$ & $\begin{array}{l}-0.0060 \\
(-1.34)\end{array}$ & $\begin{array}{l}-0.0143 \\
(-1.71)\end{array}$ & $\begin{array}{l}-0.0094 \\
(-1.50)\end{array}$ & $\begin{array}{l}0.0004 \\
(0.05)\end{array}$ & $\begin{array}{l}-0.0051 \\
(-0.86)\end{array}$ \\
\hline Germany & $\begin{array}{l}-0.0065 \\
(-1.03)\end{array}$ & $\begin{array}{l}-0.0081 \\
(-1.46)\end{array}$ & $\begin{array}{l}-0.0065 \\
(-1.29)\end{array}$ & $\begin{array}{l}-0.0012 \\
(-0.22)\end{array}$ & $\begin{array}{l}-0.0073 \\
(-1.33)\end{array}$ & $\begin{array}{l}-0.0026 \\
(-0.49)\end{array}$ & $\begin{array}{l}-0.0035 \\
(-0.69)\end{array}$ \\
\hline UK & $\begin{array}{l}-0.0064 \\
(-0.95)\end{array}$ & $\begin{array}{l}-0.0079 \\
(-1.40)\end{array}$ & $\begin{array}{l}-0.0067 \\
(-1.23)\end{array}$ & $\begin{array}{l}-0.0112 \\
(-1.50)\end{array}$ & $\begin{array}{l}-0.0058 \\
(-1.14)\end{array}$ & $\begin{array}{l}-0.0008 \\
(-0.12)\end{array}$ & $\begin{array}{l}-0.0040 \\
(-0.68)\end{array}$ \\
\hline France & $\begin{array}{l}-0.0060 \\
(-0.95)\end{array}$ & $\begin{array}{l}-0.0082 \\
(-1.44)\end{array}$ & $\begin{array}{l}-0.0069 \\
(-1.26)\end{array}$ & $\begin{array}{l}-0.0068 \\
(-1.17)\end{array}$ & $\begin{array}{l}-0.0074 \\
(-1.27)\end{array}$ & $\begin{array}{l}-0.0078 \\
(-1.26)\end{array}$ & $\begin{array}{l}-0.0035 \\
(-0.65)\end{array}$ \\
\hline Italy & $\begin{array}{r}-0.0082 \\
(-1.33) \\
\end{array}$ & $\begin{array}{r}-0.0091 \\
(-1.74) \\
\end{array}$ & $\begin{array}{r}-0.0078 \\
(-1.56) \\
\end{array}$ & $\begin{array}{l}-0.0107 \\
(-1.70) \\
\end{array}$ & $\begin{array}{l}-0.0091 \\
(-1.65) \\
\end{array}$ & $\begin{array}{r}-0.0048 \\
(-0.82) \\
\end{array}$ & $\begin{array}{l}-0.0048 \\
(-1.03) \\
\end{array}$ \\
\hline$t$-statistic & pair-wise & n slope & nces & & & & \\
\hline Canada & 1.4141 & - & - & - & - & - & - \\
\hline US & 2.1654 & 0.6612 & - & - & - & - & - \\
\hline Germany & 3.4179 & 2.0124 & 1.4381 & - & - & - & - \\
\hline UK & 3.0656 & 2.0182 & 1.3204 & 0.0019 & - & - & - \\
\hline France & 3.3800 & 2.0311 & 1.4469 & 0.0507 & 0.0337 & - & - \\
\hline Italy & 3.8996 & 2.4247 & 2.0237 & 0.6168 & 0.4388 & 0.5516 & - \\
\hline
\end{tabular}


Table 2

The pricing of country-specific risks

Entries report the estimates and $t$-statistics (in parentheses) of the following simultaneous equations under each currency denominations,

$$
R_{i, t+1}^{k}=C_{i}^{k}+A^{k} \sigma_{i m, t+1}^{k}+B^{k} \omega_{i k, t+1}+e_{i, t+1}^{k}, \quad i=1,2, \cdots, 7
$$

for $k=1, \cdots, 7$, where $R_{i, t+1}^{k}$ denotes the excess return in the country- $i$ index portfolio denominated in the $k$ th currency, $\sigma_{i m, t+1}^{k}$ measures the conditional covariance between the excess return and the global market portfolio, and $\omega_{i k, t+1}$ measures the conditional covariance between the country- $i$ portfolio excess return and the country-specific risk $E^{k, t+1}$, which is defined as the residual by regressing the country portfolio return on the global portfolio return, both under currency $k$ denomination. The estimation is based on monthly returns (in percentages) from January 1970 to December 2004. We also report in the last panel the $t$-statistics on the pair-wise differences between the slope estimates $\left(A^{k}-A^{i}\right)$ under different currency denominations.

\begin{tabular}{|c|c|c|c|c|c|c|c|}
\hline Currency & Yen & C. Dollar & Dollar & Mark & Pound & Franc & Lira \\
\hline \multicolumn{8}{|c|}{ Common slopes: } \\
\hline$\overline{A^{k}}$ & $\begin{array}{l}8.6432 \\
(2.89)\end{array}$ & $\begin{array}{l}6.0107 \\
(2.52)\end{array}$ & $\begin{array}{l}5.8178 \\
(2.61)\end{array}$ & $\begin{array}{l}3.8002 \\
(2.30)\end{array}$ & $\begin{array}{l}3.6433 \\
(2.33)\end{array}$ & $\begin{array}{l}3.7115 \\
(2.43)\end{array}$ & $\begin{array}{l}3.2901 \\
(2.32)\end{array}$ \\
\hline$B^{k}$ & $\begin{array}{l}1.9840 \\
(1.18) \\
\end{array}$ & $\begin{array}{l}0.8172 \\
(0.99) \\
\end{array}$ & $\begin{array}{r}0.9489 \\
(1.00) \\
\end{array}$ & $\begin{array}{l}0.0674 \\
(0.01) \\
\end{array}$ & $\begin{array}{l}1.2012 \\
(1.20) \\
\end{array}$ & $\begin{array}{l}0.7858 \\
(0.89) \\
\end{array}$ & $\begin{array}{l}0.0013 \\
(0.00)\end{array}$ \\
\hline \multicolumn{8}{|c|}{ Intercepts: $C_{i}^{k}$} \\
\hline Japan & $\begin{array}{l}-0.0050 \\
(-0.56)\end{array}$ & $\begin{array}{l}-0.0076 \\
(-1.40)\end{array}$ & $\begin{array}{l}-0.0026 \\
(-0.39)\end{array}$ & $\begin{array}{l}-0.0054 \\
(-0.91)\end{array}$ & $\begin{array}{l}-0.0022 \\
(-0.30)\end{array}$ & $\begin{array}{l}-0.0034 \\
(-0.56)\end{array}$ & $\begin{array}{l}-0.0039 \\
(-0.70)\end{array}$ \\
\hline Canada & $\begin{array}{l}-0.0079 \\
(-1.04)\end{array}$ & $\begin{array}{l}-0.0050 \\
(-0.90)\end{array}$ & $\begin{array}{l}-0.0087 \\
(-1.69)\end{array}$ & $\begin{array}{l}-0.0079 \\
(-1.16)\end{array}$ & $\begin{array}{l}-0.0044 \\
(-0.57)\end{array}$ & $\begin{array}{l}-0.0056 \\
(-0.82)\end{array}$ & $\begin{array}{l}-0.0058 \\
(-0.94)\end{array}$ \\
\hline US & $\begin{array}{l}-0.0070 \\
(-0.91)\end{array}$ & $\begin{array}{l}-0.0066 \\
(-1.47)\end{array}$ & $\begin{array}{l}-0.0090 \\
(-1.72)\end{array}$ & $\begin{array}{l}-0.0072 \\
(-1.08)\end{array}$ & $\begin{array}{l}-0.0036 \\
(-0.45)\end{array}$ & $\begin{array}{l}-0.0050 \\
(-0.74)\end{array}$ & $\begin{array}{l}-0.0052 \\
(-0.84)\end{array}$ \\
\hline Germany & $\begin{array}{l}-0.0061 \\
(-0.93)\end{array}$ & $\begin{array}{l}-0.0071 \\
(-1.40)\end{array}$ & $\begin{array}{l}-0.0053 \\
(-1.03)\end{array}$ & $\begin{array}{l}-0.0043 \\
(-0.86)\end{array}$ & $\begin{array}{l}-0.0029 \\
(-0.43)\end{array}$ & $\begin{array}{l}-0.0026 \\
(-0.50)\end{array}$ & $\begin{array}{l}-0.0035 \\
(-0.69)\end{array}$ \\
\hline UK & $\begin{array}{l}-0.0059 \\
(-0.85)\end{array}$ & $\begin{array}{l}-0.0072 \\
(-1.33)\end{array}$ & $\begin{array}{l}-0.0057 \\
(-1.05)\end{array}$ & $\begin{array}{l}-0.0056 \\
(-0.89)\end{array}$ & $\begin{array}{l}-0.0049 \\
(-0.94)\end{array}$ & $\begin{array}{l}-0.0031 \\
(-0.50)\end{array}$ & $\begin{array}{l}-0.0040 \\
(-0.68)\end{array}$ \\
\hline France & $\begin{array}{l}-0.0057 \\
(-0.86)\end{array}$ & $\begin{array}{l}-0.0075 \\
(-1.37)\end{array}$ & $\begin{array}{l}-0.0057 \\
(-1.02)\end{array}$ & $\begin{array}{l}-0.0047 \\
(-0.84)\end{array}$ & $\begin{array}{l}-0.0032 \\
(-0.47)\end{array}$ & $\begin{array}{l}-0.0022 \\
(-0.40)\end{array}$ & $\begin{array}{l}-0.0035 \\
(-0.64)\end{array}$ \\
\hline Italy & $\begin{array}{r}-0.0081 \\
(-1.31) \\
\end{array}$ & $\begin{array}{r}-0.0084 \\
(-1.69) \\
\end{array}$ & $\begin{array}{r}-0.0058 \\
(-1.07) \\
\end{array}$ & $\begin{array}{l}-0.0077 \\
(-1.30) \\
\end{array}$ & $\begin{array}{c}-0.0051 \\
(-0.80) \\
\end{array}$ & $\begin{array}{r}-0.0054 \\
(-0.92) \\
\end{array}$ & $\begin{array}{l}-0.0044 \\
(-0.47) \\
\end{array}$ \\
\hline \multicolumn{8}{|c|}{$t$-statistics on pair-wise common slope differences $\left(A^{k}-A^{i}\right)$ : } \\
\hline$\overline{\text { Canada }}$ & 2.5438 & - & - & $\overline{-}$ & - & - & - \\
\hline US & 2.6635 & 0.1762 & - & - & - & - & - \\
\hline Germany & 3.7062 & 2.0581 & 2.1080 & - & - & - & - \\
\hline UK & 3.9419 & 2.3417 & 2.1567 & 0.1234 & - & - & - \\
\hline France & 3.7207 & 2.1269 & 2.1110 & 0.1072 & -0.0527 & - & - \\
\hline Italy & 3.9648 & 2.6339 & 2.6890 & 0.6288 & 0.2815 & 0.5109 & - \\
\hline
\end{tabular}


Table 3

Estimating the risk-return relation using industry portfolios

Entries report the slope estimates and $t$-statistics (in parentheses) of the following simultaneous equations under each currency denominations,

$$
R_{i, t+1}^{k}=C_{i}^{k}+A^{k} \sigma_{i m, t+1}^{k}+B^{k} \omega_{i k, t+1}+e_{i, t+1}^{k}, \quad i=1,2, \cdots, 24
$$

for $k=1, \cdots, 7$, where $R_{i, t+1}^{k}$ denotes the excess return in the industry-i portfolio denominated in the $k$ th currency, $\sigma_{i m, t+1}^{k}$ measures the conditional covariance between the excess return and the global market portfolio, and $\omega_{i k, t+1}$ measures the conditional covariance between the industry- $i$ portfolio excess return and the country-specific risk $E_{k, t+1}$, which is defined as the residual by regressing the $k$ th country portfolio return on the global portfolio return, both under currency $k$ denomination. The estimation is based on monthly returns from January 1973 to December 2004. We also report the $t$-statistics on the pair-wise differences between the slope estimates $\left(A^{k}-A^{i}\right)$ under different currency denominations.

\begin{tabular}{|c|c|c|c|c|c|c|c|}
\hline Currency & Yen & C. Dollar & Dollar & Mark & Pound & Franc & Lira \\
\hline \multicolumn{8}{|c|}{ Common slopes without country-specific risk: } \\
\hline \multirow[t]{2}{*}{$\overline{A^{k}}$} & $\begin{array}{l}6.9862 \\
(2.71)\end{array}$ & $\begin{array}{l}4.8756 \\
(2.61)\end{array}$ & $\begin{array}{l}4.9532 \\
(2.68)\end{array}$ & $\begin{array}{l}3.6659 \\
(2.43)\end{array}$ & $\begin{array}{l}3.6910 \\
(2.51)\end{array}$ & $\begin{array}{l}3.5125 \\
(2.40)\end{array}$ & $\begin{array}{l}3.0124 \\
(2.32)\end{array}$ \\
\hline & \multicolumn{7}{|c|}{$t$-statistics on pair-wise common slope differences $\left(A^{k}-A^{i}\right)$ : } \\
\hline Canada & $\overline{2.8671}$ & - & - & - & - & - & - \\
\hline US & 2.7616 & -0.0943 & - & - & - & - & - \\
\hline Germany & 3.4974 & 1.6216 & 1.7256 & - & - & - & - \\
\hline UK & 3.7573 & 1.5502 & 1.6517 & -0.0369 & - & - & - \\
\hline France & 3.5804 & 1.8689 & 1.9752 & 0.1823 & 0.2693 & - & - \\
\hline Italy & 3.6458 & 2.5553 & 2.6617 & 0.8127 & 1.0244 & 0.6084 & - \\
\hline \multicolumn{8}{|c|}{ Common slopes with country-specific risk: } \\
\hline$\overline{A^{k}}$ & $\begin{array}{l}7.1002 \\
(2.74)\end{array}$ & $\begin{array}{l}4.8949 \\
(2.62)\end{array}$ & $\begin{array}{l}4.9727 \\
(2.69)\end{array}$ & $\begin{array}{l}3.6789 \\
(2.45)\end{array}$ & $\begin{array}{l}3.7032 \\
(2.51)\end{array}$ & $\begin{array}{l}3.5201 \\
(2.41)\end{array}$ & $\begin{array}{l}3.1015 \\
(2.34)\end{array}$ \\
\hline \multirow[t]{2}{*}{$B^{k}$} & $\begin{array}{l}1.2104 \\
(0.97)\end{array}$ & $\begin{array}{l}0.1212 \\
(0.01)\end{array}$ & $\begin{array}{l}0.9197 \\
(0.24)\end{array}$ & $\begin{array}{l}0.0713 \\
(0.01)\end{array}$ & $\begin{array}{l}-1.6448 \\
(-1.27)\end{array}$ & $\begin{array}{l}0.1258 \\
(0.02)\end{array}$ & $\begin{array}{l}0.0023 \\
(0.00)\end{array}$ \\
\hline & \multicolumn{7}{|c|}{$t$-statistics on pair-wise common slope differences $\left(A^{k}-A^{i}\right):$} \\
\hline Canada & $\overline{2.8413}$ & - & - & - & - & - & - \\
\hline US & 2.7062 & -0.0946 & - & - & - & - & - \\
\hline Germany & 3.5093 & 1.6301 & 1.7344 & - & - & - & - \\
\hline UK & 3.9038 & 1.5393 & 1.6613 & -0.0357 & - & - & - \\
\hline France & 3.6191 & 1.8849 & 1.9916 & 0.1887 & 0.2763 & - & - \\
\hline Italy & 3.7094 & 2.4595 & 2.5662 & 0.6862 & 0.9083 & 0.5092 & - \\
\hline
\end{tabular}


Table 4

Estimating the risk-return relation in daily frequency

Entries report the slope estimates and $t$-statistics (in parentheses) of the following simultaneous equations under each currency denominations,

$$
R_{i, t+1}^{k}=C_{i}^{k}+A^{k} \sigma_{i m, t+1}^{k}+B^{k} \omega_{i k, t+1}+e_{i, t+1}^{k}, \quad i=1,2, \cdots, n
$$

for $k=1, \cdots, 7$, where $n=7$ for country-index portfolios and 24 for industry portfolios, $R_{i, t+1}^{k}$ denotes the excess return in the $i$ th (country or industry) portfolio denominated in the $k$ th currency, $\sigma_{i m, t+1}^{k}$ measures the conditional covariance between the excess return and the global market portfolio, and $\omega_{i k, t+1}$ measures the conditional covariance between the industry- $i$ portfolio excess return and the country-specific risk $E_{t+1}^{k}$, which is defined as the residual by regressing the $k$ th country portfolio return on the global portfolio return, both under currency $k$ denomination. The estimation is based on daily returns from January 2, 1973 to December 31, 2004.

\begin{tabular}{|c|c|c|c|c|c|c|c|}
\hline Currency & Yen & C. Dollar & Dollar & Mark & Pound & Franc & Lira \\
\hline \multicolumn{8}{|c|}{ Common slopes without country-specific risk using country portfolios: } \\
\hline$A^{k}$ & $\begin{array}{l}5.9362 \\
(5.21)\end{array}$ & $\begin{array}{l}4.0398 \\
(4.31)\end{array}$ & $\begin{array}{l}4.1024 \\
(4.49)\end{array}$ & $\begin{array}{l}2.7665 \\
(3.76)\end{array}$ & $\begin{array}{l}3.8431 \\
(3.84)\end{array}$ & $\begin{array}{l}2.6214 \\
(3.41)\end{array}$ & $\begin{array}{l}2.4908 \\
(3.33)\end{array}$ \\
\hline \multicolumn{8}{|c|}{ Common slopes with country-specific risk using country portfolios: } \\
\hline$\overline{A^{k}}$ & $\begin{array}{l}5.8992 \\
(5.19)\end{array}$ & $\begin{array}{l}3.9594 \\
(4.21)\end{array}$ & $\begin{array}{l}4.0023 \\
(4.33)\end{array}$ & $\begin{array}{l}2.9043 \\
(3.91)\end{array}$ & $\begin{array}{l}3.8056 \\
(3.75)\end{array}$ & $\begin{array}{l}2.7526 \\
(3.87)\end{array}$ & $\begin{array}{l}2.3734 \\
(3.12)\end{array}$ \\
\hline$B^{k}$ & $\begin{array}{l}0.2800 \\
(0.05)\end{array}$ & $\begin{array}{l}-1.9542 \\
(-1.04)\end{array}$ & $\begin{array}{l}1.1213 \\
(1.20)\end{array}$ & $\begin{array}{l}-1.2821 \\
(-1.41)\end{array}$ & $\begin{array}{l}0.3540 \\
(0.22)\end{array}$ & $\begin{array}{l}0.3372 \\
(0.10)\end{array}$ & $\begin{array}{l}0.1079 \\
(0.03)\end{array}$ \\
\hline \multicolumn{8}{|c|}{ Common slopes without country-specific risk using industry portfolios: } \\
\hline$\overline{A^{k}}$ & $\begin{array}{l}6.9921 \\
(6.13) \\
\end{array}$ & $\begin{array}{l}4.6762 \\
(5.22) \\
\end{array}$ & $\begin{array}{l}4.4650 \\
(5.48)\end{array}$ & $\begin{array}{l}2.8210 \\
(3.89) \\
\end{array}$ & $\begin{array}{l}3.8733 \\
(4.20) \\
\end{array}$ & $\begin{array}{l}2.7754 \\
(3.81) \\
\end{array}$ & $\begin{array}{l}2.7257 \\
(3.73) \\
\end{array}$ \\
\hline \multicolumn{8}{|c|}{ Common slopes with country-specific risk using industry portfolios: } \\
\hline$\overline{A^{k}}$ & $\begin{array}{l}6.9503 \\
(6.07)\end{array}$ & $\begin{array}{l}4.5259 \\
(5.02)\end{array}$ & $\begin{array}{l}4.7627 \\
(5.73)\end{array}$ & $\begin{array}{l}2.7828 \\
(3.58)\end{array}$ & $\begin{array}{l}3.7418 \\
(4.06)\end{array}$ & $\begin{array}{l}2.7526 \\
(3.54)\end{array}$ & $\begin{array}{l}2.6951 \\
(3.59)\end{array}$ \\
\hline$B^{k}$ & $\begin{array}{l}0.4671 \\
(0.32)\end{array}$ & $\begin{array}{l}-2.5079 \\
(-1.56)\end{array}$ & $\begin{array}{l}2.5958 \\
(1.63)\end{array}$ & $\begin{array}{l}0.4766 \\
(0.15)\end{array}$ & $\begin{array}{l}-1.2230 \\
(-1.52)\end{array}$ & $\begin{array}{l}0.4239 \\
(0.25)\end{array}$ & $\begin{array}{l}0.1079 \\
(0.03)\end{array}$ \\
\hline
\end{tabular}


Table 5

The risk-return relation under asymmetric GARCH specification

Entries report the estimates and $t$-statistics (in parentheses) of the following simultaneous equations under each currency denominations,

$$
R_{i, t+1}^{k}=C_{i}^{k}+A^{k} \sigma_{i m, t+1}^{k}+B^{k} \omega_{i k, t+1}+e_{i, t+1}^{k}, \quad i=1,2, \cdots, n
$$

for $k=1, \cdots, 7$, where $n=7$ for country-index portfolios and 24 for industry portfolios, $R_{i, t+1}^{k}$ denotes the excess return in the $i$ th (country or industry) portfolio denominated in the $k$ th currency, $\sigma_{i m, t+1}^{k}$ measures the conditional covariance between the excess return and the global market portfolio, and $\omega_{i k, t+1}$ measures the conditional covariance between the industry- $i$ portfolio excess return and the country-specific risk $E_{t+1}^{k}$, which is defined as the residual by regressing the $k$ th country portfolio return on the global portfolio return, both under currency $k$ denomination. The conditional covariances are estimated based on an asymmetric GARCH specification.

\begin{tabular}{|c|c|c|c|c|c|c|c|}
\hline Country/Currency & Yen & C. Dollar & Dollar & Mark & Pound & Franc & Lira \\
\hline \multicolumn{8}{|c|}{ Common slopes without country-specific risk using country portfolios: } \\
\hline$A^{k}$ & $\begin{array}{l}7.8077 \\
(2.51) \\
\end{array}$ & $\begin{array}{l}5.8114 \\
(2.49) \\
\end{array}$ & $\begin{array}{l}5.1254 \\
(2.63) \\
\end{array}$ & $\begin{array}{l}3.6535 \\
(2.20) \\
\end{array}$ & $\begin{array}{l}3.7033 \\
(2.32) \\
\end{array}$ & $\begin{array}{l}3.3876 \\
(2.32) \\
\end{array}$ & $\begin{array}{l}3.2018 \\
(2.21) \\
\end{array}$ \\
\hline \multicolumn{8}{|c|}{ Common slopes with country-specific risk using country portfolios: } \\
\hline$\overline{A^{k}}$ & $\begin{array}{l}9.1420 \\
(3.00)\end{array}$ & $\begin{array}{l}6.1548 \\
(2.49)\end{array}$ & $\begin{array}{l}6.0425 \\
(2.60)\end{array}$ & $\begin{array}{l}3.7178 \\
(2.37)\end{array}$ & $\begin{array}{l}3.6785 \\
(2.29)\end{array}$ & $\begin{array}{l}3.3645 \\
(2.30)\end{array}$ & $\begin{array}{l}3.3880 \\
(2.29)\end{array}$ \\
\hline$B^{k}$ & $\begin{array}{l}2.1129 \\
(1.15)\end{array}$ & $\begin{array}{l}1.4282 \\
(0.39)\end{array}$ & $\begin{array}{l}2.0784 \\
(1.16)\end{array}$ & $\begin{array}{l}-0.7502 \\
(-0.80)\end{array}$ & $\begin{array}{l}1.8081 \\
(1.02)\end{array}$ & $\begin{array}{l}1.2597 \\
(0.98)\end{array}$ & $\begin{array}{l}0.0193 \\
(0.01)\end{array}$ \\
\hline \multicolumn{8}{|c|}{ Common slopes without country-specific risk using industry portfolios: } \\
\hline$\overline{A^{k}}$ & $\begin{array}{l}7.5411 \\
(2.60)\end{array}$ & $\begin{array}{l}5.8212 \\
(2.55)\end{array}$ & $\begin{array}{l}5.5199 \\
(2.67)\end{array}$ & $\begin{array}{l}4.3252 \\
(2.32)\end{array}$ & $\begin{array}{l}4.3747 \\
(2.49)\end{array}$ & $\begin{array}{l}4.2492 \\
(2.38)\end{array}$ & $\begin{array}{l}3.8451 \\
(2.35)\end{array}$ \\
\hline \multicolumn{8}{|c|}{ Common slopes with country-specific risk using industry portfolios: } \\
\hline$\overline{A^{k}}$ & $\begin{array}{l}8.3177 \\
(2.80)\end{array}$ & $\begin{array}{l}6.0055 \\
(2.56)\end{array}$ & $\begin{array}{l}5.9649 \\
(2.64)\end{array}$ & $\begin{array}{l}4.3657 \\
(2.37)\end{array}$ & $\begin{array}{l}4.3059 \\
(2.36)\end{array}$ & $\begin{array}{l}4.2166 \\
(2.36)\end{array}$ & $\begin{array}{l}3.8964 \\
(2.31)\end{array}$ \\
\hline$B^{k}$ & $\begin{array}{l}1.4702 \\
(0.64)\end{array}$ & $\begin{array}{l}0.7884 \\
(0.69)\end{array}$ & $\begin{array}{l}1.0513 \\
(0.92)\end{array}$ & $\begin{array}{l}0.0410 \\
(0.01)\end{array}$ & $\begin{array}{l}1.4544 \\
(1.16)\end{array}$ & $\begin{array}{l}0.9047 \\
(0.85)\end{array}$ & $\begin{array}{l}0.0500 \\
(0.00)\end{array}$ \\
\hline
\end{tabular}

